\title{
Occurrence and Diversity of Xanthomonas campestris pv. campestris in Vegetable Brassica Fields in Nepal
}

Brita Dahl Jensen, Department of Plant Biology and Biotechnology and Department of Agriculture and Ecology, The Faculty of Life Sciences, University of Copenhagen, Thorvaldsensvej 40, 1871 Frederiksberg C, Denmark; Joana G. Vicente, Warwick HRI, The University of Warwick, Wellesbourne, Warwick CV35 9EF, UK; Hira K. Manandhar, Plant Pathology Division, Nepal Agricultural Research Council, Khumaltar, Lalitpur, Nepal; and Steven J. Roberts, Plant Health Solutions, Warwick CV34 5NU, UK

\begin{abstract}
Jensen, B. D., Vicente, J. G., Manandhar, H. K., and Roberts, S. J. 2010. Occurrence and diversity of Xanthomonas campestris pv. campestris in vegetable Brassica fields in Nepal. Plant Dis. 94:298-305.

Black rot caused by Xanthomonas campestris pv. campestris was found in 28 sampled cabbage fields in five major cabbage-growing districts in Nepal in 2001 and in four cauliflower fields in two districts and a leaf mustard seed bed in 2003. Pathogenic X. campestris pv. campestris strains were obtained from 39 cabbage plants, 4 cauliflower plants, and 1 leaf mustard plant with typical lesions. Repetitive DNA polymerase chain reaction-based fingerprinting (rep-PCR) using repetitive extragenic palindromic, enterobacterial repetitive intergenic consensus, and BOX primers was used to assess the genetic diversity. Strains were also race typed using a differential series of Brassica spp. Cabbage strains belonged to five races (races 1, 4, 5, 6, and 7), with races 4,1 , and 6 the most common. All cauliflower strains were race 4 and the leaf mustard strain was race 6. A dendrogram derived from the combined rep-PCR profiles showed that the Nepalese $X$. campestris pv. campestris strains clustered separately from other Xanthomonas spp. and pathovars. Race 1 strains clustered together and strains of races 4,5 , and 6 were each split into at least two clusters. The presence of different races and the genetic variability of the pathogen should be considered when resistant cultivars are bred and introduced into regions in Nepal to control black rot of brassicas.
\end{abstract}

Cabbage and cauliflower production increased significantly in Nepal during the 1990 s; in 2004-05, nearly 20,000 ha were cultivated with cabbage, accounting for $11 \%$ of the vegetable area in Nepal (3). Cabbage is considered an important cash crop and, in some areas, production is almost continuous, with up to three crops per year. The production increase has been accompanied by an increase in the use of commercial hybrid seed (32).

Black rot, caused by the vascular bacterium Xanthomonas campestris pv. campestris, is one of the most serious diseases of vegetable Brassica spp. (4,43). Typical disease symptoms in the field are Vshaped, chlorotic to necrotic lesions starting from leaf margins and with blackening of the vascular tissue $(33,43)$. Blight symptoms have also been reported (45). Black rot of crucifers was reported in Nepal in 1977 (30). Adhikari and Basnyat (1) found that 20 strains of $X$. campestris pv. campestris from broccoli, cabbage, and

Corresponding author: B. D. Jensen

E-mail: dahl@life.ku.dk

Accepted for publication 28 October 2009.

doi:10.1094/PDIS-94-3-0298

(C) 2010 The American Phytopathological Society cauliflower from the Kathmandu and Chitwan valleys had similar biochemical and physiological characteristics but strains from Chitwan tended to be more aggressive on cabbage, cauliflower, and broccoli than strains from the Kathmandu Valley.

Until 2007, six races of $X$. campestris pv. campestris were defined on the basis of their reactions on a differential set that includes genotypes of Brassica oleracea, B. rapa, B. juncea, B. napus, and B. carinata $(14,40)$. A gene-for-gene model has been proposed to explain the interactions between the races and the differential cultivars (40). Races 1, 4, and 6 are the most frequently reported races $(11,39,40)$. In 2007, race 7 was reported in Belgium by Fargier and Manceau (8), along with races 8 and 9, which had a narrower host range on differential cultivars. We also found race 7 in this study, and a preliminary report of our work appeared in 2007 (13).

Conserved, repetitive DNA sequences in bacteria have been targeted for use in distinguishing bacterial species and strains by the polymerase chain reaction (PCR) $(7,37,38)$, using primers specific to the repetitive extragenic palindromic (REP) sequence (10), the enterobacterial repetitive intergenic consensus (ERIC) sequence (28), and the BOX element (17). Previous studies have shown the potential of repeti- tive DNA PCR-based fingerprinting (rep$\mathrm{PCR})$ to differentiate Xanthomonas pathovars $(20,21,26,41)$ and strains within pathovars $(16,20)$; therefore, rep-PCR could be used as a diagnostic tool in plant pathology.

Some strains of $X$. campestris pv. campestris have been characterized by genetic fingerprinting using rep-PCR. $X$. campestris pv. campestris strains from Tanzania tended to cluster within local geographical areas (18) and, similarly, it was found that $X$. campestris pv. campestris strains from different countries, to some extent, clustered within larger geographical regions (35), whereas this was not the case in a study carried out on Italian strains (46). Results of rep-PCR fingerprinting allowed the separation of $X$. campestris pv. campestris from $X$. campestris pv. raphani strains, and showed that, among $X$. campestris pv. campestris and $X$. campestris pv. raphani strains, there was a tendency for strains of the same race to cluster together (41). Rep-PCR, amplified fragment length polymorphism, pulsedfield gel electrophoresis, and integron gene cassette PCR was used to study the diversity of $22 X$. campestris pv. campestris strains and revealed $11,12,13$, and 4 differentiated genotypes, respectively, supporting the heterogeneous nature and relatively high level of diversity in this pathovar $(36,46)$.

The aim of this work was to (i) study the occurrence of black rot in Brassica fields in major cabbage-growing regions of $\mathrm{Ne}$ pal and (ii) characterize the diversity of the $X$. campestris pv. campestris strains by rep-PCR fingerprinting and race typing on a set of differential Brassica spp. genotypes with the aim to suggest efficient control strategies involving breeding, introduction, and cultivation of resistant cultivars.

\section{MATERIALS AND METHODS}

The work was divided into three steps: (i) collection of black-rot-infected leaf material in Nepal; (ii) isolation of $X$. campestris pv. campestris and pathogenicity testing at the Faculty of Life Sciences, Denmark; and (iii) further pathogenicity testing, rep-PCR, and race typing at Warwick HRI, The University of Warwick, UK. 
Collection of black-rot-infected leaf samples. Twenty-eight white cabbage $(B$. oleracea var. capitata) fields, each at least 10 by $10 \mathrm{~m}$, were sampled in five major cabbage-growing areas (five districts in four zones) in the eastern, central, and western parts of Nepal (Fig. 1; Table 1) during the monsoon season in July 2001. According to farmers' information, the cultivar grown was usually Green Coronet $F_{1}$. From each field, a leaf with typical black rot symptoms (V-shaped lesions) was sampled from each of 10 wellseparated plants. In 2003, single plants in four cauliflower (B. oleracea var. botrytis) fields were sampled, and a single sample was collected from a seedbed of leaf mustard (B. juncea). Samples were dried between sheets of paper at room temperature before isolation of the causal agent. The altitude of each field was recorded using a hand-held GPS device (eTrex Venture GPS Navigator; Garmin Corporation, Taiwan).

Isolations. One or two leaf samples, representing one or two plants from each field, were selected for isolation of the causal agent from the typical V-shaped lesions. From each leaf sample, 0.5 to 1 $\mathrm{cm}^{2}$ of leaf tissue was excised with a sterile scalpel from the margin of a lesion and placed in a drop of sterile $0.85 \%$ saline for
5 min. A loopful of saline suspension from a point with bacterial ooze was streaked on nutrient starch cycloheximide agar (NSCA) (23) and incubated at $28^{\circ} \mathrm{C}$ for 48 to $72 \mathrm{~h}$ and observed for typical $X$. campestris pv. campestris colonies (pale yellow, mucoid, starch-hydrolyzing). A typical colony from each isolation plate was subcultured to yeast dextrose calcium carbonate agar (YDC) (31) and then transferred to sucrose-peptone agar (SPA) for viscosity testing (19). For most isolations, an additional colony originating from a second NSCA plate was subcultured and the strain was kept as a "duplicate." All isolates with a flow time of more than $30 \mathrm{~s}$ (19) were subsequently tested for pathogenicity. Isolates were stored at $-80^{\circ} \mathrm{C}$ in cryovials (Simport Cryovial, Canada) containing glass beads and nutrient broth plus $15 \%$ glycerol (9), or in Protect cryovials (Technical Service Consultants Ltd., Lancashire, UK).

Pathogenicity. Isolates were tested for pathogenicity on six 3- to 4-week-old plants of cabbage cv. Copenhagen Market (L. Daehnfeldt, Denmark), grown in 12by-13- $\mathrm{cm}^{2}$ pots in a peat-based compost (Weibulls Enhetsjord, K-Jord, Svalöf Weibull Trädgärd AB, Hammenhög, Sweden) in a glasshouse at 20 to $25^{\circ} \mathrm{C}$. Each

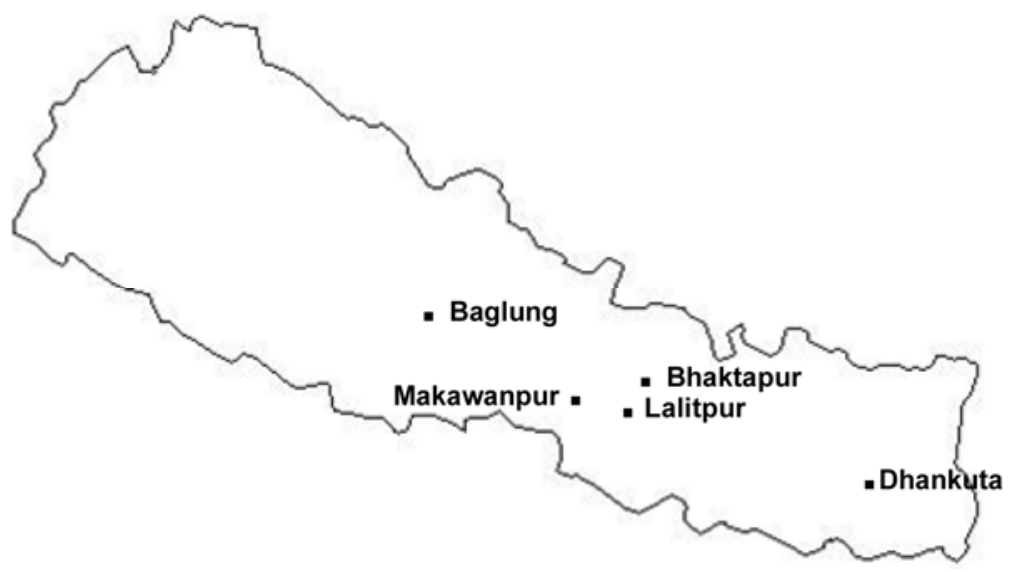

Fig. 1. Cabbage-growing areas (districts) from which leaves with typical black rot symptoms were collected in 2001 and confirmed to be caused by Xanthomonas campestris pv. campestris in the present study. (Map courtesy of Matt Rosenberg, Geography at About.com: http://geography.about.com). isolate was tested twice (different inoculation date). Bacteria were grown on YDC agar at $28^{\circ} \mathrm{C}$ for $48 \mathrm{~h}$, and inoculum was prepared by suspending a small amount of growth in $0.85 \%$ saline. The suspensions were adjusted to a final concentration of approximately $10^{8} \mathrm{CFU} \mathrm{m} \mathrm{m}^{-1}$ by dilution. Each pot with six plants was sprayed with $10 \mathrm{ml}$ of bacterial suspension using a hand-held plastic atomizer (KAB1005, KABI, Denmark) at a distance of approximately $15 \mathrm{~cm}$ from the plants. After inoculation, plants were maintained in a transparent polyethylene tent for $48 \mathrm{~h}$ to increase the humidity. The temperature varied between 25 and $35^{\circ} \mathrm{C}$ during the experiment with a day length of approximately $16 \mathrm{~h}$. The six plants were assessed for symptoms ( $\mathrm{V}$-shaped lesions) 2 and 3 weeks after inoculation; isolates were considered pathogenic when V-shaped lesions occurred on at least three plants. In addition, the pathogenicity of 20 isolates was tested on individual 4-week-old Savoy cabbage plants (B. oleracea var. sabauda) of cv. Wirosa $F_{1}$ (Bejo Zaaden, The Netherlands) using the inoculation method of Vicente et al. (41). Plants were raised from seed sown in $6.5-\mathrm{cm}^{2}$ plastic pots with Levington M2 compost (Scotts, England) in a glasshouse with a minimum temperature of 20 and $15^{\circ} \mathrm{C}$ and venting at 22 and $17^{\circ} \mathrm{C}$ (day and night, respectively), and with supplementary lighting to give a 16-h photoperiod. Isolates were grown on YDC medium for $48 \mathrm{~h}$ at $30^{\circ} \mathrm{C}$. The three youngest leaves of 4-week-old plants were inoculated at six sites near the leaf margin and three sites in the midrib using a sterile pin charged with growth from a YDC plate (41). One plant was inoculated per isolate but the inoculations were repeated if the first results indicated that the isolate was weak or not pathogenic. The presence of symptoms was recorded 2 and 3 weeks after inoculation (40).

rep-PCR fingerprinting. DNA extraction and rep-PCR amplification was done for all pathogenic isolates from Nepal (44 independent strains plus 32 duplicate strains from the same leaf) and 2 reference strains, representing two commonly found

Table 1. Cabbage-growing areas in the lower hills of the Himalayas and the Kathmandu valley visited July 2001, the altitude, number of fields sampled with black rot symptoms, number of fields from which Xanthomonas campestris pv. campestris isolation was attempted, and the number of strains included in repetitive DNA polymerase chain reaction-based fingerprinting (rep-PCR) and race typing

\begin{tabular}{|c|c|c|c|c|c|c|c|}
\hline \multirow[b]{2}{*}{ Region } & \multirow[b]{2}{*}{ Zone } & \multirow[b]{2}{*}{ District } & \multirow[b]{2}{*}{ Altitude (m) } & \multirow[b]{2}{*}{ Black rot ${ }^{\mathbf{b}}$} & \multirow[b]{2}{*}{ Isolation $^{c}$} & \multicolumn{2}{|c|}{ Number of strains ${ }^{a}$} \\
\hline & & & & & & rep-PCR ${ }^{d}$ & Race typed $^{\mathrm{e}}$ \\
\hline Western & Dhawalagiri & Baglung & $1,521-69$ & 3 & 2 & $4(+3)$ & $4(+1)$ \\
\hline Central & Bagmati & Lalitpur & $1,430-84$ & 7 & 5 & $13(+7)$ & $13(+2)$ \\
\hline Central & Bagmati & Bhaktapur & $1,296-1,304$ & 2 & 2 & $5(+4)$ & $5(+1)$ \\
\hline Central & Narayani & Makawanpur & $1,710-1,950$ & 7 & 3 & $6(+6)$ & $6(+1)$ \\
\hline Eastern & Koshi & Dhankuta & $1,734-2,139$ & 9 & 6 & $11(+10)$ & $11\left(+2^{\mathrm{e}}\right)$ \\
\hline Total & $\ldots$ & $\ldots$ & $\ldots$ & 28 & 18 & $39(+30)$ & $39\left(+7^{\mathrm{e}}\right)$ \\
\hline
\end{tabular}

${ }^{a}$ Number of strains obtained from individual plants; parentheses indicate the number of duplicate strains that were also tested $(+x)$.

${ }^{\mathrm{b}}$ Sampled fields with black rot symptoms.

${ }^{\mathrm{c}}$ Fields from which isolation was carried out.

${ }^{\mathrm{d}}$ Pathogenicity test positive and rep-PCR carried out.

${ }^{e}$ Race typing included one pair of strains from the same plant that had different rep-PCR profiles. 
races, HRI 1279A (race 4) and HRI 3811 (race 1) under the same laboratory conditions at Warwick HRI as previously reported (41).

All samples, "blank" control lanes using water as template, and the two reference strains were included at the same time in each of the rep-PCR setups. From each strain and blank controls, 6- $\mu \mathrm{l}$ aliquots (REP and ERIC primer sets) and 2.5- $\mu$ l aliquots (BOX primer) of amplified PCR products were separated by electrophoresis in $1.2 \%$ agarose 22-lane gels (41). A molecular mass marker (1-Kb Plus DNA Ladder, Invitrogen) was loaded on both sides and central lanes, and the two reference strains were loaded on all gels. Gels were visualized on a UV transilluminator and photographed on an imaging system (ImaGo; B \& L Systems, The Netherlands). A digital image of each gel was analyzed using the GelCompar II Software (Applied Maths, Kortrijk, Belgium). Gels were normalized using the molecular mass markers; optimization settings were chosen which maximized the similarity of the strains, which were repeated on each gel. Bands of less than $500 \mathrm{bp}$ (REP), $400 \mathrm{bp}$ (ERIC), and $300 \mathrm{bp}$ (BOX) and larger than $4,000 \mathrm{bp}$ were excluded from the analysis. The normalized data generated from BOX, ERIC, and REP fingerprinting profiles were combined. The similarity between profiles was calculated using the Pearson product-moment correlation coefficient. Cluster analysis of the pairwise similarity values was performed using the unweighted pair group with arithmetic means algorithm. For comparative purposes, profiles of additional strains, representing all six races of $X$. campestris pv. campestris, three races of $X$. campestris pv. raphani, three strains of other $X$. campestris pathovars, and two strains of other Xanthomonas spp. generated previously under the same laboratory conditions as used here (41) were included in the analysis.

Race typing. In all, 44 independent strains from Nepal and 7 duplicate strains (obtained from the same plants) were race typed. Race typing was carried out using a set of differential Brassica spp. using the method and experimental conditions at
Warwick HRI as previously described (40), with the following modifications: the doubled-haploid lines Cob60 and FBLM2 and the inbred line Bo99075, derived from B. napus cv. Cobra line 14R, B. juncea cv. Florida Broad Leaf Mustard, and B. carinata accession PI 199947, respectively, replaced the lines from which they were originally derived. In addition, the doubled-haploid line SxD1, derived from a cross between $B$. oleracea cv. Böhmerwaldkohl and a rapid cycling line, was also tested to confirm the results obtained with Miracle $F_{1}$. The differentials used are included in Table 2. Three plants of 'Seven Top Turnip' and one plant of each of the other genotypes were inoculated with each strain. One control strain of race 5 (HRI 3880) was also race typed for comparison.

Plants were raised in the glasshouse as described above for the pathogenicity test on Wirosa $F_{1}$. Strains were grown on YDC medium for $48 \mathrm{~h}$ at $30^{\circ} \mathrm{C}$ and suspended in $0.85 \%$ saline to produce a turbid suspension containing approximately $10^{8}$ to $10^{9}$ $\mathrm{CFU} \mathrm{ml} \mathrm{m}^{-1}$. The three youngest leaves of 4week-old plants were inoculated by clipping the veins near the leaf margins with mouse-tooth forceps, with teeth wrapped in absorbent cotton wool and dipped in the bacterial suspension (40). Disease assessments were carried out 2 and 3 weeks after inoculation (40).

\section{RESULTS}

Occurrence of black rot and symptoms in the field. Black rot symptoms were commonly observed in all 28 cabbage fields visited and sampled in the five major cabbage-growing districts in Nepal during the monsoon season in July 2001 (Fig. 1; Table 1). The altitude of the fields ranged from 1,296 to $2,139 \mathrm{~m}$. Most samples were collected from fields in Lalitpur, Dhankuta, and Makawanpur districts, because cabbage production was at its peak at the time of sampling, whereas most fields had already been harvested in Bhaktapur and Baglung districts. Typical Vshaped, chlorotic lesions with black veins were found on leaves in all fields, regardless of plant maturity. In some fields, mature heads exhibited blackening of the vascular stem tissue when cut in half. In 2003, the four cauliflower fields and the seedbed of leaf mustard visited also exhibited typical symptoms: V-shaped, chlorotic lesions with dark veins. Blight symptoms were not observed.

Isolations and pathogenicity. Isolates from 39 cabbage plants, 4 cauliflower plants, and 1 leaf mustard plant produced yellow mucoid growth on YDC and a positive viscosity test (Tables 1 and 3 ). In addition, 30 duplicate isolates from the same cabbage plants and 2 duplicate isolates from the cauliflower plants also had the above typical characteristics. The isolates all produced clear and distinct V-shaped lesions on leaves of B. oleracea cv. Copenhagen Market, Wirosa $F_{1}$, or both and were considered to be $X$. campestris $\mathrm{pv}$. campestris.

rep-PCR fingerprinting. All 39 cabbage strains, the 4 cauliflower strains, and the leaf mustard strain, together with the 32 duplicate strains from Nepal and the 2 reference strains, HRI 1279A (race 4) and HRI 3811 (race 1), were fingerprinted using rep-PCR (Table 1). The rep-PCR fingerprint profiles, obtained with the BOX, ERIC, and REP primers, confirmed that all isolates were strains of $X$. campestris pv. campestris. These profiles were complex and revealed polymorphic bands among $X$. campestris pv. campestris strains. The combined dendrogram had a cophenetic correlation coefficient of 0.95 . The separate dendrograms obtained with REP, ERIC, and BOX had cophenetic correlations of $0.93,0.94$, and 0.88 respectively (data not shown).

The profiles of the two reference strains (HRI 1279A and 3811) that were repeated in five different gels had similarities ranging from 88.6 to $97.7 \%$ and 81.1 (in one gel) to $95.3 \%$, respectively, with most profiles of the same strain having similarities greater than $93 \%$. Thus, the separation of strains with similarities greater than $80 \%$ might not be reliable, and strains with a similarity greater than approximately $90 \%$ might be identical.

All, except 1 of the pairs of strains originating from a single lesion (30 pairs from cabbage and 2 from cauliflower

Table 2. Brassica accessions used in pathogenicity tests to identify Xanthomonas campestris pv. campestris races

\begin{tabular}{|c|c|c|c|c|c|c|c|c|c|c|}
\hline \multirow[b]{2}{*}{ Genotype } & \multirow[b]{2}{*}{ Species } & \multirow[b]{2}{*}{ Source $^{\mathbf{b}}$} & \multirow[b]{2}{*}{ Type } & \multicolumn{7}{|c|}{ Interaction with race ${ }^{a}$} \\
\hline & & & & 1 & 2 & 3 & 4 & 5 & 6 & 7 \\
\hline Wirosa $F_{1}$ & Brassica oleracea & Bejo & Hybrid & + & + & + & + & + & + & + \\
\hline Just Right Hybrid Turnip & B. rapa & Otis & Hybrid & + & + & + & - & + & + & + \\
\hline Cob60 & B. napus & WHRI & Doubled haploid & + & + & + & - & + & + & + \\
\hline Seven Top Turnip & B. rapa & Otis & Open pollinated & + & - & + & $-1+$ & $-/+$ & + & + \\
\hline Bo99075 (PI 199947) & B. carinata & WHRI & Inbred line & - & + & - & - & + & + & + \\
\hline FBLM 2 & B. juncea & Otis & Doubled haploid & - & + & - & - & $-/(+)$ & + & - \\
\hline Miracle $F_{1}$ & B. oleracea & Bejo & Hybrid & + & - & - & + & - & $(+) /+$ & + \\
\hline SxD1 & B. oleracea & WHRI & Doubled haploid & + & - & - & + & - & $(+) /+$ & + \\
\hline
\end{tabular}

a Symbols: +, compatible interaction (susceptible host); -, incompatible interaction (resistant host); (+), weakly pathogenic; $-/+$, variable result within accession. Adapted from Vicente et al. (2001) based on unpublished results and results of the present study.

${ }^{\mathrm{b}}$ Seed sources: Bejo = Bejo Zaden, Warmenhuizen, Holland; WHRI = Warwick HRI, The University of Warwick, United Kingdom; Otis = Otis S. Twilley Seed Co., United States. 
plants) produced fingerprint profiles that were identical (i.e., with a similarity $\geq 90 \%$ ). The pair of strains (N47 and N48) obtained from the same lesion had distinct profiles (similarity of $81.9 \%$, with profiles obtained on the same gel runs).

A dendrogram was constructed (Fig. 2) with the results from Nepalese strains from 39 individual cabbage plants, of which 1 plant is represented by 2 strains (N47 and N48), 4 strains from cauliflower, 1 strain from leaf mustard, 15 strains representative of the six races of $X$. campestris pv. campestris, and 8 strains of other Xanthomonas spp. and pathovars. All X. campestris pv. campestris strains from Nepal and all reference $X$. campestris pv. campestris strains, except race 2 , formed a single cluster at $44.8 \%$ similarity. This group was differentiated from the other $X$. campestris pathovars and other Xanthomonas spp. X. campestris pv. campestris race 2 , of which only a single strain has been obtained (39), is clearly distinct from other $X$. campestris pv. campestris strains. At $70 \%$ similarity, the $X$. campestris pv. campestris strains separated into a large group of 29 strains (containing 21 strains from four districts of Nepal), a group of 12 Nepalese strains (from four districts of Nepal), a group of 11 strains (containing 9 Nepalese strains from three districts of Nepal), 2 strains from Nepal (N68 and N70), 2 strains from Portugal and Nepal (HRI 6185 and N8, respectively), and 3 individual strains (HRI 6181, HRI 3880, and HRI 6312A). At 80\% similarity, the group of 29 strains split into two major groups (containing 9 and 13 strains) and three minor groups containing 2 strains and an individual strain (HRI 6412); the group of 12 strains split into a group of 8 strains, a group of 2 strains (N35 and N47) and 2 single strains (N55 and N34); the group of 11 strains remained clustered.

Race typing. In all, 39 cabbage $X$. campestris pv. campestris strains, 7 duplicate strains, 4 cauliflower strains, and 1 leaf mustard strain from Nepal plus the race 5 type-strain (HRI 3880) were inoculated into the differential set (Table 2). Four of the six previously described races, namely $1,4,5$, and 6 , were identified (Tables 3 and 4). In cabbage, on an individual plant basis, 14 strains were identified as race 4,12 strains as race 1,9 strains as race 6 , and 3 strains as race 5 . Races 2 and

Table 3. Origin of Xanthomonas campestris pv. campestris strains and the results of pathogenicity testing and race typing

\begin{tabular}{|c|c|c|c|c|c|c|}
\hline \multirow[b]{2}{*}{ HRI no. } & \multirow[b]{2}{*}{ Original no. $^{b}$} & \multirow[b]{2}{*}{ Crop } & \multirow[b]{2}{*}{ District/field no. } & \multicolumn{2}{|c|}{ Pathogenicity on cvs.a } & \multirow[b]{2}{*}{ Race } \\
\hline & & & & Copenhagen Market & Wirosa & \\
\hline \multicolumn{7}{|c|}{ Collected in 2001} \\
\hline 8429 A & N1 & Cabbage & Lalitpur/2 & + & nt & $6^{\mathrm{c}}$ \\
\hline 8430 & N5 & Cabbage & Lalitpur/2 & + & nt & 4 \\
\hline $8431 \mathrm{~A}$ & N6 & Cabbage & Lalitpur/3 & + & nt & $4^{c}$ \\
\hline 8432 & N8 & Cabbage & Lalitpur/3 & + & nt & 6 \\
\hline 8434 & N11 & Cabbage & Lalitpur/4 & + & nt & 1 \\
\hline $8435 \mathrm{~A}$ & $\mathrm{~N} 12$ & Cabbage & Lalitpur/4 & + & nt & 4 \\
\hline $8388 \mathrm{~A} / \mathrm{B}$ & N14/N15 & Cabbage & Lalitpur/4 & + & nt & 4 \\
\hline 8389 & N16 & Cabbage & Lalitpur/4 & + & nt & 4 \\
\hline 8436 B & N18 & Cabbage & Lalitpur/5 & + & nt & 4 \\
\hline $8437 \mathrm{~A}$ & N25 & Cabbage & Lalitpur/5 & + & + & 1 \\
\hline $8390 \mathrm{~A} / \mathrm{B}$ & $\mathrm{N} 20 / \mathrm{N} 21$ & Cabbage & Lalitpur/6 & + & + & $4^{c}$ \\
\hline 8439 A & N22 & Cabbage & Lalitpur/6 & + & nt & 1 \\
\hline 8440 & $\mathrm{~N} 27$ & Cabbage & Lalitpur/6 & + & nt & 4 \\
\hline $8441 \mathrm{~A}$ & N29 & Cabbage & Dhankuta/3 & + & nt & 1 \\
\hline $8442 \mathrm{~A}$ & N31 & Cabbage & Dhankuta/3 & + & nt & 1 \\
\hline 8443 B & N34 & Cabbage & Dhankuta/5 & + & nt & $5^{\mathrm{c}}$ \\
\hline $8444 \mathrm{~A}$ & N35 & Cabbage & Dhankuta/5 & + & nt & $7^{\mathrm{c}}$ \\
\hline $8445 \mathrm{~A} / \mathrm{B}$ & N37/N38 & Cabbage & Dhankuta/6 & + & nt & 1 \\
\hline 8446 & $\mathrm{~N} 40$ & Cabbage & Dhankuta/7 & + & nt & $6^{c}$ \\
\hline 8447 A & N41 & Cabbage & Dhankuta/7 & + & nt & 1 \\
\hline $8448 \mathrm{~A}$ & N43 & Cabbage & Dhankuta/8 & + & nt & $6^{\mathrm{c}}$ \\
\hline 8449 A & N45 & Cabbage & Dhankuta/8 & + & nt & 4 \\
\hline $8450 \mathrm{~A}$ & N47 & Cabbage & Dhankuta/9 & + & nt & $7^{\mathrm{c}}$ \\
\hline $8450 \mathrm{~B}$ & N48 & Cabbage & Dhankuta/9 & + & $\mathrm{nt}$ & $6^{c}$ \\
\hline $8451 \mathrm{~A}$ & N49 & Cabbage & Dhankuta/9 & + & nt & 6 \\
\hline $8452 \mathrm{~A} / \mathrm{B}$ & N51/N52 & Cabbage & Makawanpur/1 & + & nt & 1 \\
\hline 8453 B & N54 & Cabbage & Makawanpur/1 & + & nt & 4 \\
\hline $8454 \mathrm{~A}$ & N55 & Cabbage & Makawanpur/4 & + & nt & $6^{\mathrm{c}}$ \\
\hline $8455 \mathrm{~A}$ & N57 & Cabbage & Makawanpur/4 & + & nt & 1 \\
\hline $8456 \mathrm{~A}$ & N59 & Cabbage & Makawanpur/7 & + & nt & 1 \\
\hline $8457 \mathrm{~A}$ & N61 & Cabbage & Makawanpur/7 & + & nt & 1 \\
\hline $8458 \mathrm{~A} / \mathrm{B}$ & N63/N64 & Cabbage & Baglung/1 & + & nt & $6^{c}$ \\
\hline $8459 \mathrm{~B}$ & N66 & Cabbage & Baglung/1 & + & + & 6 \\
\hline $8460 \mathrm{~B}$ & N68 & Cabbage & Baglung/2 & + & $\mathrm{nt}$ & $5^{\mathrm{c}}$ \\
\hline 8461 B & N70 & Cabbage & Baglung/2 & + & + & 5 \\
\hline $8462 \mathrm{~A} / \mathrm{B}$ & N71/N72 & Cabbage & Bhaktapur/1 & + & + & 1 \\
\hline $8463 \mathrm{~A}$ & N77 & Cabbage & Bhaktapur/1 & $\mathrm{nt}$ & + & 4 \\
\hline 8464 B & N74 & Cabbage & Bhaktapur/3 & + & nt & 4 \\
\hline $8465 \mathrm{~A}$ & N75 & Cabbage & Bhaktapur/3 & + & $\mathrm{nt}$ & 4 \\
\hline 8466 & N79 & Cabbage & Bhaktapur/3 & nt & + & 4 \\
\hline \multicolumn{7}{|c|}{ Collected in 2003} \\
\hline $8467 \mathrm{~A}$ & N81 & Cauliflower & Dhankuta/10 & nt & + & 4 \\
\hline $8468 \mathrm{~A}$ & N83 & Cauliflower & Lalitpur/7 & $\mathrm{nt}$ & + & 4 \\
\hline 8469 & N85 & Cauliflower & Lalitpur/8 & + & + & 4 \\
\hline 8471 & N87 & Leaf mustard & Lalitpur/10 & + & + & $6^{\mathrm{c}}$ \\
\hline 8472 & N88 & Cauliflower & Lalitpur/11 & nt & + & 4 \\
\hline
\end{tabular}

a Symbols: +, compatible interaction; nt, not tested.

${ }^{\mathrm{b}}$ Two numbers indicate that duplicate strains from the same plant were tested with the same results.

${ }^{c}$ Duplicate strains or one strain were tested twice in two separate experiments. 
3 were not found. Race 6 strains were generally pathogenic on all differentials but weakly pathogenic on $B$. oleracea $\mathrm{cv}$. Miracle $F_{1}$ and line SxD1. Two strains, N35 and N47, were pathogenic and very aggressive on all genotypes except $B$. juncea line FBLM2. This was an unknown differential reaction at the time of the experiments, and these strains were assigned to race 7 (13). Seven plants were repre- sented by seven pairs (duplicates) of strains from the same lesion (Table 3). These pairs of strains were the same race type, except for one pair (N47 and N48), which were identified as races 6 and 7 , respectively (Table 3 ). Races 4,1 , and 6 were the most common in cabbage and were all found in four of the five districts (Table 4). Races 5 and 7 were represented by three and two of the strains, respec- tively (Table 4). Race 5 was identified in two of the districts and race 7 in only one district. The four strains from cauliflower were all race 4 and the leaf mustard strain was race 6 (Tables 3 and 4). Cabbage production in the Dhankuta district was intensive at the time of sampling, and all five races identified in this study were present. Three races were identified amongst the 13 strains from Lalitpur (Table 4) whereas

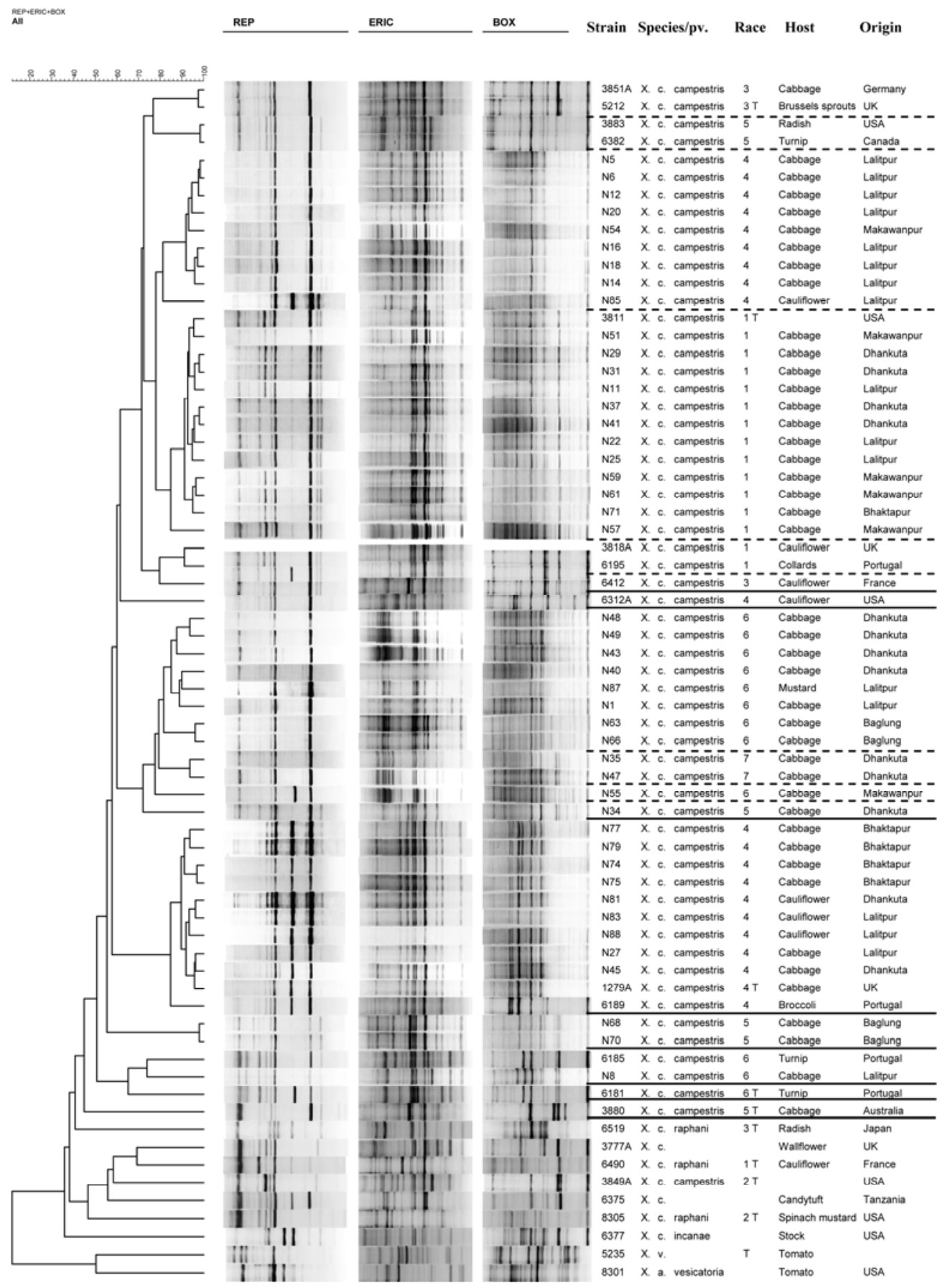

Fig. 2. Dendrogram of the genetic similarity of 40 race-typed Nepalese Xanthomonas campestris pv. campestris strains from cabbage, 4 from cauliflower, and 1 from leaf mustard, analyzed together with two control strains of X. campestris pv. campestris (HRI 1279A and 3811), and combined with previous fingerprinting data from 13 X. campestris pv. campestris and 8 other Xanthomonas sp. strains (including representative strains of X. campestris pvs. raphani and incanae, $X$. campestris strains from wallflower and candytuft, $X$. vesicatoria, and X. axonopodis pv. vesicatoria) from Vicente et al. (2006). Race type strains of $X$. campestris pv. campestris and X. campestris pv. raphani and type strain of $X$. vesicatoria are indicated with a T. Similarities were calculated from the combined data of polymerase chain reaction fingerprinting using repetitive extragenic palindromic (REP), enterobacterial repetitive intergenic consensus (ERIC), and BOX primer sets. Strain numbers without a prefix are HRI numbers. Solid and dashed lines delimit the most important groups of strains at 70 and $80 \%$ similarity, respectively. 
two or three races were identified on the basis of a more limited number of strains in the other districts. More than one race was present in 11 of 17 tested cabbage fields, on the basis of tests of strains from two to three plants per field (Table 3 ).

Typical black rot symptoms were frequent on inoculated plants, and dark, necrotic blight symptoms were observed in some cases. Blight-like symptoms were frequently produced by race 7 strains and by some strains of races 5 and 6 and a few strains of race 1 , but not race 4 strains.

Combining rep-PCR fingerprinting, race affiliation, and geographical origin. The geographical origin of the Nepalese strains does not seem to be correlated with the rep-PCR clusters shown in the combined dendrogram (Fig. 2). The clusters seem to be more related to the race of the strains. All 12 Nepalese X. campestris pv. campestris race 1 strains formed a single subcluster at $85 \%$ similarity jointly with the race 1 reference strain (HRI 3811) from the United States. The $X$. campestris pv. campestris race 4 strains were divided among two distinct clusters containing 9 and 11 strains at 81 and $85 \%$ similarity, respectively. The latter group included the race 4 reference strain (HRI 1279A) with rep-PCR profiles from the present study and a race 4 strain (HRI 6189) from a previous study $(40,41)$. Strains from the Lalitpur district were included in both race 4 clusters, even at the field level (strains N20/21 and N27). Most of the race 1 strains and strains in each of the race 4 clusters might be identical. Two Nepalese race 5 strains (N68 and N70) were identical and distinct from another race 5 Nepalese strain (N34). Nine race 6 and the two race 7 Nepalese $X$. campestris pv. campestris cabbage strains were included in the same cluster at $77 \%$ similarity. One Nepalese race 6 strain (N8) clustered with the race 6 reference strain from Portugal.

\section{DISCUSSION}

The present study supports previous findings related to the occurrence of black rot in Nepal and the diversity of the causal bacterium, $X$. campestris pv. campestris $(1,27)$, and it confirms that the disease is widespread in the vegetable Brassica spp.growing areas in the country. Symptoms of black rot were observed in all visited fields, in seedbeds, in newly transplanted crops, and in mature crops. The disease is frequently overlooked by farmers and extension workers, who observe symptoms but mistakenly think they are related to natural plant senescence. The increased and almost continuous production of Brassica crops in some areas, and the ability of $X$. campestris pv. campestris to spread by seed movement (42) and rain splash (43) and to survive in plant debris left in the field (24), may cause build up and maintenance of inoculum, thereby increasing the impact of the disease in the future unless appropriate control measures are adopted.

A significant proportion of cabbage seed is imported to Nepal (32), and it is important to ensure that such seed is tested and free of the pathogen to minimize the risk of introduction of additional new races or pathotypes. Selection of cultivars with disease resistance is another means of control $(12,34,43)$, which should be considered in combination with crop rotation and sanitation schemes.

V-shaped leaf lesions with black veins, typical of black rot $(6,44)$, were frequently observed in the fields, and $X$. campestris pv. campestris was isolated from these lesions regardless of the crop growth stage. Blight symptoms, characterized by a sudden collapse of interveinal tissues and lack of veinal necrosis at earlier stages of infection, similar to those observed in Hawaii $(29,45)$ and in the United Kingdom (S. J. Roberts, unpublished), were not observed in the Nepalese fields. However, during race typing under controlled conditions, we observed both typical black rot symptoms and blight-like symptoms, especially in plants inoculated with strains of races 5 , 6 , and 7. A previous study has also shown that inoculation of $B$. oleracea accessions with race 5 and 6 strains more commonly produced blight symptoms than when inoculated with other races (40). The blight symptoms appeared similar to those previously described (2) after artificial inoculation under greenhouse conditions.

In this study, duplicate isolates obtained from the same lesion produced similar repPCR profiles, except in one case, where two isolates belonged to different races. This suggests that rep-PCR can be used for rapid initial screening of isolates to select nonidentical ones for further analysis, including race typing. The race affiliation of the two isolates from the same or adjacent lesions was tested twice to ensure that the result was reproducible. The results, in general, indicate that most leaf lesions from which isolations were made were a result of infection by a single race of the pathogen. However, the two races obtained from the same leaf indicate that mixed infections, or leaf lesions with a race mixture produced as the result of merged lesions from several infection points, may develop if more than one race is present in the field. This is not unlikely because different races were identified at the field level in more than half of the cabbage fields sampled in this study.

rep-PCR of strains of $X$. campestris pv. campestris from different geographic regions of Nepal produced fingerprinting profiles for races 1, 4, and 6 that clustered according to races and different lineages therein. Nepalese race 1 strains formed a single cluster, and strains of races 4,5 , and 6 were split into at least two clusters. All strains of race 4 and 6 , except one strain of each race, clustered in two separate clusters. Previously, it had also been found that $X$. campestris pv. raphani and a selection of $X$. campestris pv. campestris strains clustered in accordance with races (40). In contrast, it was concluded, on the basis of rep-PCR (with REP and BOX primers only), that fingerprints of $X$. campestris pv. campestris strains from Tanzania (18) and Nepalese strains (27) were related to geographical origin but the races of these strains were not determined, and it is possible that different races were present in different areas. We found (data not shown) that the ERIC primers, which were not included in that study (18), are the most important for discriminating between $X$. campestris pv. campestris races. ERICPCR also revealed a higher level of genetic diversity than REP and BOX primers in a previous study of $X$. axonopodis pvs. phaseoli and phaseoli var. fuscans (15). Another study showed that two X. campestris pv. campestris race 3 strains had different rep-PCR fingerprinting profiles (or were grouped in different clusters) and suggested that race affiliation cannot be inferred by DNA fingerprinting (36). However, the 14 Israeli strains were not race typed. More recently, results of fingerprints using BOX-PCR and M13-PCR of $X$. campestris pv. campestris strains from Italy were not correlated with geographical and host origin (45). Other rep-PCR studies of other Xanthomonas spp. and pathovars have shown grouping of strains affiliated with distinct symptom groups (22), geographical origin (25), and year of isolations (26). This indicates that the potential to use rep-PCR to differentiate pathogenic variants within a pathovar may depend on several parameters.

Table 4. Frequency of occurrence of Xanthomonas campestris pv. campestris races among 40 strains obtained from cabbage plants in five districts in Nepal

\begin{tabular}{|c|c|c|c|c|c|c|}
\hline \multirow[b]{2}{*}{ District } & \multicolumn{5}{|c|}{ Number of strains of race } & \multirow[b]{2}{*}{ Total } \\
\hline & 1 & 4 & 5 & 6 & 7 & \\
\hline Baglung & $\ldots$ & $\ldots$ & 2 & 2 & $\ldots$ & 4 \\
\hline Lalitpur & 3 & 8 & $\ldots$ & 2 & $\ldots$ & 13 \\
\hline Bhaktapur & 1 & 4 & $\ldots$ & $\ldots$ & $\ldots$ & 5 \\
\hline Makawanpur & 4 & 1 & $\ldots$ & 1 & $\ldots$ & 6 \\
\hline Dhankuta & 4 & 1 & 1 & $4^{\mathrm{a}}$ & $2^{\mathrm{a}}$ & 12 \\
\hline Total & $12(30.0 \%)$ & $14(35.0 \%)$ & $3(7.5 \%)$ & $9(22.5 \%)$ & $2(5 \%)$ & 40 \\
\hline
\end{tabular}

a In one case, two races were obtained from the same lesion (plant). 
Five races of $X$. campestris pv. campestris were found in Nepal, with races 1, 4, and 6 dominating. The dominance of races 1 and 4 has also been reported from other countries, and the other races were considered rare (40). A previous study (39) also showed the presence and dominance of race 4 , followed by race 1 and 6 , among 51 strains from Portugal, mainly from $B$. oleracea; in that study, race 4 accounted for $53 \%$ of the strains, race 6 for $29 \%$, and race 1 for $18 \%$. In contrast, race typing of 102 strains from the United Kingdom, mainly from $B$. oleracea (including 68 strains from cauliflower), showed that race 1 dominated (69\%) followed by race 4 (30\%); a single strain of race 3 was also identified in the U.K. collection (40). The presence of race 5 has previously been reported for only three strains of older origin (1953 to 1975; 40), which suggested that these races might not exist anymore. However, our study revealed that race 5 still exists, although at low frequency (7\%). The two lineages of races 4 and 6 may suggest two different origins for these races or that races 4 and 6 have evolved into two distinct lineages, which might even be different races, not yet identified by lack of discerning differentials.

Two strains, N35 and N47, were pathogenic and very aggressive on all genotypes except on B. juncea line FBLM2, and were assigned to race 7 . Differences in the ability of the strains to cause disease in artificial inoculation tests were also revealed previously with Nepalese strains from the Katmandu and Chitwan valleys (1). Florida Broad Leaved Mustard (FBLM2) is compatible with (i.e., susceptible to) $X$. campestris pv. campestris race 6 but not with the new race $7(8,13)$. It has been shown that mutants of $X$. campestris pv. campestris race 1 with insertions or deletions in $\operatorname{avrXccFM}$ become virulent on Florida Broad Leaf Mustard (5). Similarly, in this way, a single gene difference may determine the difference in compatibility between races 6 and 7 on Florida Broad Leaf Mustard. The rep-PCR clustering of the two races indicate a close relatedness between these two races; therefore, it is possible that they may differ only in the presence of an avirulence ( $a v r$ ) gene.

More than one race was identified in all districts and there were no obvious differences in the race composition within the geographically isolated regions sampled. Most cabbage seed is imported and, during sampling, it became evident that one cultivar dominated in all growing areas. This may imply that the pathogen was introduced into the areas with the seed. However, many factors play a role in the occurrence and diversity of the pathogen (for instance, tight crop rotation schemes with cabbage and other Brassica spp. crops) and may, together, contribute to the occurrence and diversity of the pathogen.
Race typing of strains is time, space, and labor intensive. This study has shown that fingerprinting of strains using the combined rep-PCR profiles (REP, ERIC, and BOX primer sets) has potential to differentiate species, pathovars, pathotypes, and lineages within $X$. campestris pv. campestris. The presence of several races of the bacterium within Nepal, including the new race 7 , emphasizes the need for local surveys of $X$. campestris pv. campestris to gain insight into the population composition and change. The results may be of value in relation to regulatory issues, such as seed import, but also highlight the need to account for pathogenic diversity when breeding, introducing, and cultivating resistant cultivars to control the disease.

\section{ACKNOWLEDGMENTS}

This study was supported by Danida, Denmark (RUF, grant no. 91013, and 91116) and by the Department for Environment, Food and Rural Affairs (Defra), UK. Some of the work in the United Kingdom was done under a Defra Plant Health Licence (PHL 166C/4499). We thank L. Bailey and S. McClement from WHRI, University of Warwick, for providing doubled-haploid accessions; P. P. Kathiwada (Agriculture Research Station, Pakhribas, Nepal), B. A. C. (Dhaulagiri Community Resource and Development Centre, Baglung, Nepal), and K. Budhatoki (Horticulture Research Division, Nepal Agricultural Research Council, Khumaltar) for locating the crops; G. P. Parajuli (Plant Pathology Division, Nepal Agricultural Research Council, Khumaltar) for assistance with the collection of infected leaf samples; and all farmers for welcoming us onto their land and allowing collection of diseased material.

\section{LITERATURE CITED}

1. Adhikari, T. B., and Basnyat, R. 1999. Phenotypic characteristics of Xanthomonas campestris pv. campestris from Nepal. Eur. J. Plant Pathol. 105:303-305.

2. Alvarez, A. M., Benedict, A. A., Mizumoto, C. Y., Hunter, J. E., and Gabriel, D. W. 1994. Serological, pathological, and genetic diversity among strains of Xanthomonas campestris infecting crucifers. Phytopathology 84:14491457.

3. Anonymous. 2006. Annual Report. Vegetable Development Directorate, Department of Agriculture, Khumaltar, Lalitpur, Nepal.

4. Cab International. 2006. Crop Protection Compendium, 2006 Edition. CAB International, Wallingford, UK.

5. Castañeda, A., Reddy, J. D., El-Yacoubi, B., and Gabriel, D. W. 2005. Mutagenesis of all eight avr genes in Xanthomonas campestris pv. campestris had no detected effect on pathogenicity, but one $a v r$ gene affected race specificity. Mol. Plant-Microbe Interact. 18:13061317.

6. Cook, A. A., Walker, J. C., and Larson, R. H. 1952. Studies on the disease cycle of black rot of crucifers. Phytopathology 42:162-167.

7. De Bruijn, F. J. 1992. Use of repetitive (repetitive extragenic palindromic and enterobacterial repetitive intergeneric consensus) sequences and the polymerase chain reaction to fingerprint the genomes of Rhizobium meliloti isolates and other soil bacteria. Appl. Environ. Microbiol. 58:2180-2187.

8. Fargier, E., and Manceau, C. 2007. Pathogenicity assays restrict the species Xanthomonas campestris into three pathovars and reveal nine races within $X$. campestris pv. campestris. Plant Pathol. 56:805-818.
9. Feltham, R. K. A., Power, A. K., Pell, P. A. and Sneath, P. H. A. 1978. A simple method for storage of bacteria at $-76^{\circ} \mathrm{C}$. J. Appl. Bacteriol. 44:313-316.

10. Higgins, C. F., Ames, G. F.-L., Barnes, W. M., Clement, J. M., and Hofnung, M. 1982. A novel intercistronic regulatory element of prokaryotic operons. Nature 298:760-762.

11. Ignatov, A., Hida, K., and Kuginuki, Y. 1998. Black rot of crucifers and sources of resistance in brassica crops. Jpn. Agric. Res. Q. 32:167172.

12. Jensen, B. D., Massomo, S. M. S., Swai, I. S., Hockenhull, J., and Andersen, S. B. 2005 Field evaluation for resistance to the black rot pathogen Xanthomonas campestris pv campestris in cabbage (Brassica oleracea). Eur. J. Plant Pathol. 113:297-308.

13. Jensen, B. D., Vicente, J. G., Manandhar, H. K., and Roberts, S. J. 2007. An increasing risk for bacterial plant diseases in Northern Europe? Occurrence and diversity of Xanthomonas campestris pv. campestris in vegetable Brassica fields in Nepal and identification of a new race. In: Abstract Book, Plant Biotech Denmark, Annual Meeting, Faculty of Life Sciences, University of Copenhagen, Denmark.

14. Kamoun, S., Kamdar, H. V., Tola, E., and Kado, C. I. 1992. Incompatible interactions between crucifers and Xanthomonas campestris involve a vascular hypersensitive response: role of the hrpx locus. Mol. Plant-Microbe Interact. 5:22-33.

15. López, R., Asensio, C., and Gilbertson, R. L. 2006. Phenotypic and genetic diversity in strains of common blight bacteria (Xanthomonas campestris pv. phaseoli and X. campestris pv. phaseoli var. fuscans) in a secondary center of diversity of the common bean host suggests multiple introduction events. Phytopathology 96:1204-1213.

16. Louws, F. J., Fulbright, D. W., Stephens, C. T. and De Bruijn, F. J. 1994. Specific genomic fingerprints of phytopathogenic Xanthomonas and Pseudomonas pathovars and strains generated with repetitive sequences and PCR. Appl. Environ. Microbiol. 60:2286-2295.

17. Martin, C., Briese, T., and Hakenbeck, R. 1992. Nucleotide-sequences of genes encoding penicillin-binding proteins from Streptococcus pneumoniae and Streptococcus oralis with high homology to Escherichia coli penicillinbinding proteins $1 \mathrm{~A}$ and $1 \mathrm{~B}$. J. Bacteriol. 174:4517-4523

18. Massomo, S. M. S., Nielsen, H., Mabagala, R. B., Mansfeld-Giese, K., Hockenhull, J., and Mortensen, C. N. 2003. Identification and characterisation of Xanthomonas campestris pv. campestris strains from Tanzania by pathogenicity tests, Biolog, rep-PCR and fatty acid methyl ester analysis. Eur. J. Plant Pathol. 109:775-789.

19. Pierce, L., Schroth, M. N., and McCain, A. H. 1990. Viscosity test for preliminary identification of strains of Xanthomonas campestris. Plant Dis. 74:646-647.

20. Rademaker, J. L. W., Louws, F. J., Schultz, M. H., Rossbach, U., Vauterin, L., Swings, J., and De Bruijn, F. J. 2005. A comprehensive species to strain taxonomic framework for Xanthomonas. Phytopathology 95:1098-1111.

21. Rademaker, J. L. W., Norman, D. J., Forster, R. L., Louws, F. J., Schultz, M. H., and De Bruijn, F. J. 2006. Classification and identification of Xanthomonas translucens isolates, including those pathogenic to ornamental asparagus. Phytopathology 96:876-884.

22. Sahin, F., Abbasi, P. A., Ivey, M. L. L., Zhang, J., and Miller, S. A. 2003. Diversity among strains of Xanthomonas campestris pv. vitians from lettuce. Phytopathology 93:64-70.

23. Schaad, N. W., and Kendrick, R. 1975. A qualitative method for detecting Xanthomonas 
campestris in crucifer seed. Phytopathology 65:1034-1036

24. Schaad, N. W., and White, W. C. 1974. Survival of Xanthomonas campestris in soil. Phytopathology 64:1518-1520.

25. Scortichini, M., Marchesi, U., and Di Prospero, P. 2001. Genetic diversity of Xanthomonas arboricola pv. juglandis (synonyms: $X$. campestris pv. juglandis; $X$. juglandis pv. juglandis) strains from different geographical areas shown by repetitive polymerase chain reaction genomic fingerprinting. J. Phytopathol. 149:325-332.

26. Scortichini, M., and Rossi, M. P. 2003. Genetic diversity of Xanthomonas arboricola pv. fragariae strains and comparison with some other $X$. arboricola pathovars using repetitive PCR genomic fingerprinting. J. Phytopathol. 151:113-119.

27. Shakya, D. D., Louws, F. J., and Alvarez, A. M. 2000. Diversity of Xanthomonas campestris pv. campestris $(X c c)$ populations in Nepal. (Abstr.) Phytopathology 90:S71.

28. Sharples, G. J., and Lloyd, R. G. 1990. A novel repeated DNA sequence located in the intergenic regions of bacterial chromosomes. $\mathrm{Nu}$ cleic Acids Res. 18:6503-6508.

29. Shigaki, T., Nelson, S. C., and Alvarez, A. M. 2000. Symptomless spread of blight-inducing strains of Xanthomonas campestris pv. campestris on cabbage seedlings in misted seedbeds. Eur. J. Plant Pathol. 106:339-346.

30. Shrestha, K., Mathur, S. B., and Neergaard, P. 1977. Seed-borne organisms in some crops of Nepal. Seed Sci. Technol. 5:111-121.

31. Stolp, H., and Starr, M. P. 1964. Bacteriophage reactions and speciation of phytopathogenic xanthomonads. J. Phytopathol. 51:442-478.
32. Subedi, G. D., and K.C., R. B. 2004. Scenario of hybrid vegetable seed use in Nepal. Pages 275-281 in: Advances of Horticultural Research in Nepal. B. B. Khatri, B. P. Sharma, P. P. Khatiwada, K. P. Paudyal, B. R. Khadge, and H. N. Regmi, eds. Proc. Fourth Natl. Workshop Horticulture. Nepal Agricultural Research Council, National Agricultural Research Institute and Horticulture Research Division, Khumaltar, Lalitpur, Nepal.

33. Sutton, J. C., and Williams, P. H. 1970. Relation of xylem plugging to black rot lesion development in cabbage. Can. J. Bot. 48:391401.

34. Taylor, J. D., Conway, J., Roberts, S. J., Astley, D., and Vicente, J. G. 2002. Sources and origin of resistance to Xanthomonas campestris pv. campestris in Brassica genomes. Phytopathology 92:105-111.

35. Tsygankova, S. V., Ignatov, A. N., Boulygina, E. S., Kuznetsov, B. B., and Korotkov, E. V. 2004. Genetic relationships among strains of Xanthomonas campestris pv. campestris revealed by novel rep-PCR primers. Eur. J. Plant Pathol. 110:845-853.

36. Valverde, A., Hubert, T., Stolov, A., Dagar, A., Kopelowitz, J., and Burdman, S. 2007. Assessment of genetic diversity of Xanthomonas campestris pv. campestris isolates from Israel by various DNA fingerprinting techniques. Plant Pathol. 56:17-25.

37. Versalovic, J., Koeuth, T., and Lupski, J. R. 1991. Distribution of repetitive DNAsequences in eubacteria and application to fingerprinting of bacterial genomes. Nucleic Acids Res. 19:6823-6831.

38. Versalovic, J., Schneider, M., De Bruijn, F. J., and Lupski, J. R. 1994. Genomic fingerprinting of bacteria using repetitive sequence-based polymerase chain reaction. Methods Mol. Cell. Biol. 5:25-40.

39. Vicente, J. G. 2004. A Podridão Negra das Cruciferas. Centro Operativo e Tecnológico Hortofrutícola Nacional, Alcobaça, Portugal.

40. Vicente, J. G., Conway, J., Roberts, S. J., and Taylor, J. D. 2001. Identification and origin of Xanthomonas campestris pv. campestris races and related pathovars. Phytopathology 91:492 499.

41. Vicente, J. G., Everett, B., and Roberts, S. J. 2006. Identification of isolates that cause a leaf spot disease of brassicas as Xanthomonas campestris pv. raphani and pathogenic and genetic comparison with related pathovars. Phytopathology 96:735-745.

42. Walker, J. C., and Tisdale, W. B. 1920. Observations on seed transmission of the cabbage black rot organism. Phytopathology 10:175177.

43. Williams, P. H. 1980. Black rot: a continuing threat to world crucifers. Plant Dis. 64:736 742.

44. Williams, P. H., Staub, T., and Sutton, J. C. 1972. Inheritance of resistance in cabbage to black rot. Phytopathology 62:247-252.

45. Yuen, G. Y. K., and Alvarez, A. M. 1985. Aberrant symptoms on cabbage caused by strains of Xanthomonas campestris. (Abstr.) Phytopathology 75:1382.

46. Zaccardelli, M., Campanile, F., Moretti, C., and Buonaurio, R. 2008. Characterization of Italian populations of Xanthomonas campestris pv. campestris using primers based on DNA repetitive sequences. J. Plant Pathol. 90:375381. 